\title{
MODELLING FINANCIALSTABILITY INDEX FOR LATVIAN FINANCIAL SYSTEM
}

\author{
KIRILS KONDRATOVS ${ }^{1}$ \\ University of Latvia (Latvia)
}

\begin{abstract}
Financial disturbances can be costly. In particular, systemic events in financial markets, such as banking crises, often affect the whole society in a deeply traumatising way. Consequently, it is important to anticipate risks of such adverse development so as to try to prevent that kind of disaster and ensure financial stability. Author of this paper analyses fragility of financial system of Latvia to the fluctuations in global economy and changes in direction of international capital flows by creating complex financial system stability index. Results have proven that dynamics of every developed sub-index show unique economic processes defining Latvian financial system's stability. Secondly, sub-indices analysis allows to determine that Latvian financial vulnerability began to worsen in 2005, however, Latvian financial stability downward movement started in 2002, that in its turn shows the necessity for Latvian economic policy makers to get more actively involved in preventing growing risks of economy. Latvian financial system stability index established in this working paper and its accompanying methodology can be further used in follow-up research and Latvian financial stability index improvement.

KEYWORDS: financial system, financial stability, index modeling.
\end{abstract}

JEL CODE: G01

\section{Introduction}

Financial disturbances can be costly. In particular, systemic events in financial markets, such as banking crises, often affect the whole society in a deeply traumatising way. Consequently, it is important to anticipate the risks of such adverse development so as to try to prevent that kind of disaster and ensure financial stability. The object of the research - Latvian financial system. This paper aims at construction of financial fragility composite index for Latvian financial system and estimating econometric model that describes mentioned index development. The objectives set for the research are:

- to examine international experience of statistical indicators usage when evaluating financial stability;

- to establish complex stability index for financial system of Latvia;

- to model stability index using econometric error correction model.

Following research methods have been used during working paper development: literature review (its generalization, systematization and visualization), statistical analyses and econometric modelling. Econometric modelling has been performed using EViews software. Quarterly data sample (from 2001: 2 till 2011: 1) has been collected from Financial and Capital Market Commission of Latvia, Bank of Latvia, Central Statistical Bureau of Latvia, statistical office of the European Union, Research Institute of the Centre for Economic Studies.

1 Kirils Kondratovs - University of Latvia, Faculty of Economics and Management, Ph.D. student. Scientific interest: econometrics, macro financial management.

E-mail: kiril.kondratov@burko.eu Tel.: +37129231204. 


\section{International experience of statistical indicators usage \\ when evaluating financial stability}

In last twenty years researchers, including ones from central banks, have been trying to identify conditions that would ensure financial stability. For this purpose they have used various statistical indicators that characterize and describe vulnerability of financial system.

In reality many central banks in their financial stability reports try to evaluate financial stability related risks while only focusing on few main indicators. Furthermore there are efforts to create unified tools that would allow evaluating level of financial instability or stress.

There are significant advantages to financial systems stability qualitative tools that would allow to follow developments in financial system if compared to qualitative measuring. Qualitative tools would allow policy creators and financial systems participants to: $\{1\}$ better supervise level of financial system stability; $\{2\}$ forecast sources and consequences of financial stress; $\{3\}$ communicate with other institutions and population on current situation and forecasted development in a more efficient manner.

Čihák (Čihák, 2007: 1-2) in his publication defines following characteristics of a good financial stability indicator can be easily calculated, easily interpreted, is based on adequate assumptions and has clear theoretical base.

Author of this working paper will evaluate newly established Latvian financial stability indicator taking into account financial stability indicators characteristics that were mentioned earlier. However in author's opinion there are 2 more characteristics of a good financial stability indicator - it gives true Figure if applied to historical data; it can be economically modelled using fundamental factors of national economy.

Approach on forming and developing financial stability assessment tools has changed with the course of time. Eventually centre of attention for financial stability assessment and supervision has shifted from micro to macro level. If before early warning indicators that reflected risk of insolvency for specific institutions were analysed then now central position has been taken by assessment of broad financial market risks, institutional and infrastructure risks.

Supervision of financial system at macrolevel is very important and after last world financial crisis it has become even more urgent. For example, in 2010 UK Financial Services Authority chanirman A. Turner said: "We need a new set of macro-prudential policy tools which will enable the authorities more directly to influence the supply of credit [...] These tools are needed because credit/asset price cycles can be key drivers of macroeconomic volatility and potential financial instability" (Turner, 2010: 1). In 2010 H. Hanoun (Hannoun, 2010: 1-26), deputy General Manager of the Bank for International Settlements, offered to add a level of macro-prudential policy to the micro-prudential policy base, therefore eliminating systemic risks. In H. Hannoun's opinion this additional level would have two important aspects: its goal would be to ensure stability in the course of time; it would ensure financial system stability in any given time period.

As it is seen from above macro supervision plays a great part in ensuring financial stability. Therefore development of relevant tools in order to effectively supervise macro economy is crucial. Policy makers and academic researchers focus on several quantitative indicators aiming to assess financial stability. International Monetary Fund developed set of financial stability indicators (IMF, 2006: 75-87); also Hawkins and Klau (Hawkins, Klau, 2000), Nelson and Perli (Nelson, Perli, 2005), Gray and others (Gray, Merton, Bodie, 2007) work can be metioned as examples. Figure below summarizes sectors of economy that are usually analysed in scope of financial stability assessment in research papers (see Figure 1).

Analysing real sector the most often used statistical indicators are: GDP changes trend and pace; fiscal position of government; inflation.

Pace and trend of GDP changes indicate economy health and development potential. GDP is an important indicator, especially in conjunction with such economic indicators as loans volume and fiscal deficit. Negative or low GDP trend points to economy in recession. Excessively high GDP trend could indicate economy overheating and unsustainable growth. 


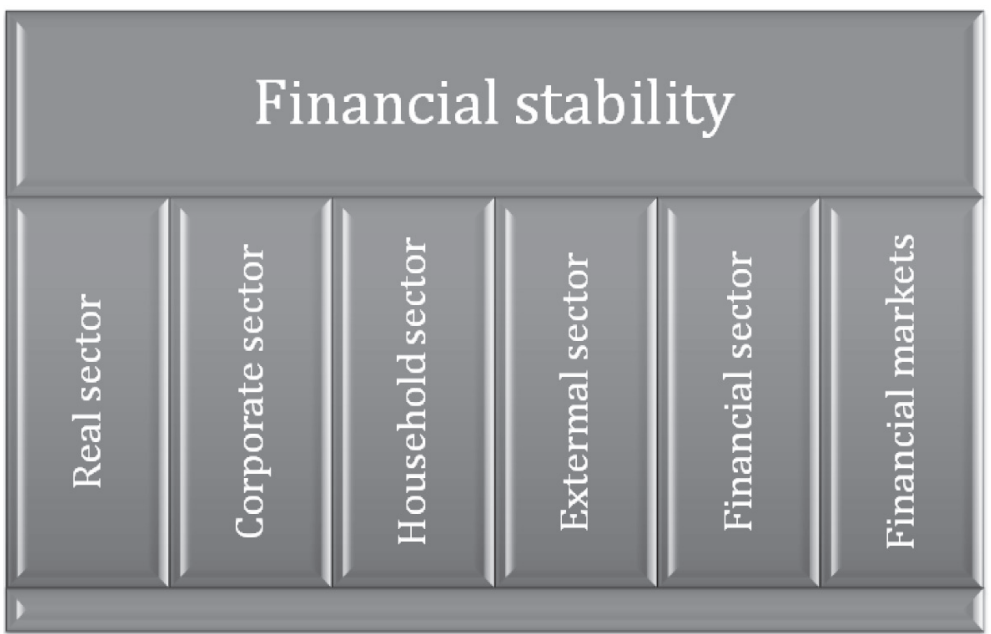

Figure 1. Sectors of economy that get usually analysed in scope of financial stability assessment

Source: Blaise and Kaushik work "Measures of financial stability” (Blaise, Kaushik, 2009: 367-369), author's Figure

Government's fiscal position shows possibility to attract additional funding for its unbalanced expenses. High level of sovereign debt to GDP indicates relatively unsustainable sovereign debt and country exposure. In scope of inflation various price indices dynamics are assessed. High inflation indicates weakening of economy structure, debt increase and also increasing risk of external competitive capacity decline. Too low inflation could encourage financial bubbles.

Similar economic indicators describing above mentioned sectors' development and related financial stability risks are used both in scientific research papers and central banks' financial stability reports (see Figure 1). It is noteworthy that some central banks actively use composite indices (see Table 1. Use of composite indices in financial stability reports).

Table 1. Use of composite indices in financial stability reports

\begin{tabular}{|c|c|c|c|c|}
\hline & $\begin{array}{c}\text { Financial stability } \\
\text { index }\end{array}$ & Banking index & $\begin{array}{l}\text { Index of financial } \\
\text { condition }\end{array}$ & $\begin{array}{l}\text { Monetary condition } \\
\text { index }\end{array}$ \\
\hline Czech Republic & & $\mathrm{X}$ & & \\
\hline Switzerland & & $\mathrm{X}$ & $\mathrm{X}$ & \\
\hline UK & $\mathrm{X}$ & & $\mathrm{X}$ & \\
\hline Hungary & & & $\mathrm{X}$ & \\
\hline Turkey & & $\mathrm{X}$ & & \\
\hline ECB & & & $\mathrm{X}$ & \\
\hline IMF & $\mathrm{X}$ & $\mathrm{X}$ & $\mathrm{X}$ & \\
\hline
\end{tabular}

Source: Blaise and Kaushik work "Measures of financial stability" (Blaise, Kaushik, 2009: 373-374)

However, as it can be seen from the table, use of composite indices for financial stability assessment is not yet widely spread and used indices are primarily indices of banking and financial state. Interesting fact is that none of the mentioned countries and international institutions has developed monetary condition index. According to publicly available information none of the above mentioned composite indices has yet been developed and used for financial stability analysis in Latvia. All that together even further stresses the importance of this working paper. Composite indices advantages and development opportunities and principles are discussed in the next part of this working paper. 


\section{Establishment of Latvian Financial System Stability Index}

In 2010 Albulescu created composite financial stability index for Romania, thus greatly contributing to the development of financial stability assessment methodology described in research literature (Albulescu, 2010: 81-98). Approach described in his publication is taken as a base for Latvian financial stability index establishment. Working paper's author will analyse available statistical data and will establish new Latvian financial stability assessment method that will be specifically adjusted for Latvian economic conditions. Working paper's author establishes Latvian financial system stability index using five sub-indices that are also established by this working paper's author and that describe development of Latvian financial system. These 5 sub-indices are incorporated in one system with the development of domestic and foreign economic and financial environment (see Figure 2): (a) financial development index, (b) financial vulnerability index, (c) financial stability index, (d) European economic environment index and (e) European financial environment index.

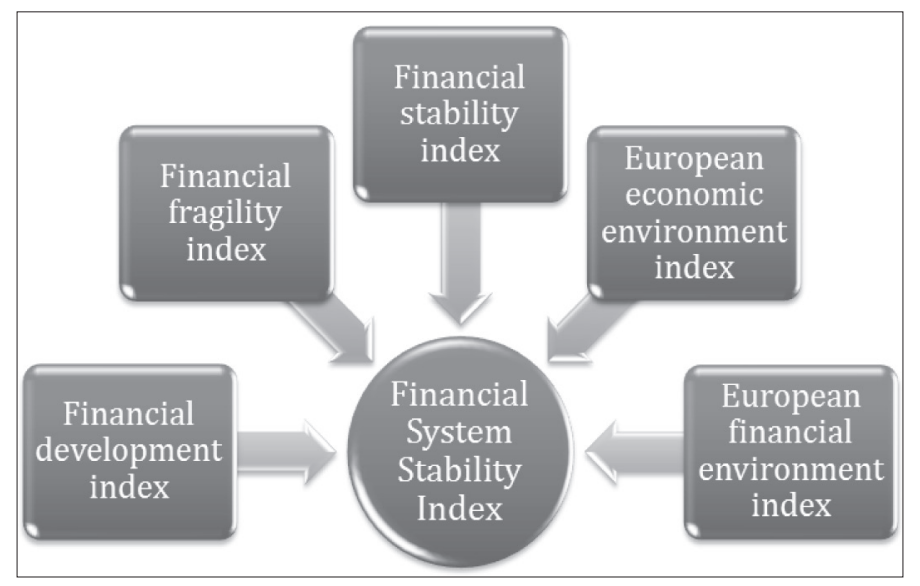

Figure 2. Latvian Financial System Stability Index comprising indices

Source: author's Figure

(a) Financial development index

Working paper's author derives financial development index from 10 statistical indicators that describe Latvian financial system development and its effectiveness: ratio of financial market level of capitalization to GDP; ratio of disbursed Latvian lat (LVL) loans to GDP; ROE; ROA; banks funding effective interest rate; effective deposit interest rate; effective loan interest rate; net interest income margin; interest rate spread; banks reforms and interest rates liberalization index.

(b) Financial vulnerability index: share of credit to households for housing purchases in credit total issued to residents; loans issued to non-banks to deposits; ratio of total deposits to M2 (broad money); share of demand deposits in total deposits.

(c) Financial stability index: inflation level; ratio of state budget deficit to GDP; ratio of current account deficit to GDP; real effective exchange rate value increase or deterioration.

(d) European economic environment index: Eurozone economics climate index; Eurozone inflation level; Eurozone growth rate.

(e) European financial environment index:

Respectively, in order to develop European financial environment index paper's author has used data on harmonized long-term interest rates for Eurozone countries that are evaluated by the ECB and that represent government bonds with 10 year maturity. Variance is calculated from selected interest rates; in author's opinion this variance characterizes financial environment of the Eurozone.

After data selection composite index is calculated as a weighted average of chosen variables. Method of weighting indicators can differ: using overall factors analysis; weights can be chosen based on the size 
and importance of the market that is described by specific economic indicator; using sample's cumulative distribution function; using macroeconomic model's simulation results; assigning identical weights to all economic indicators.

Last approach is the most common and includes indicators' normalization and establishing of composite index using same indicators' weight. Blaise and Kaushik (Blaise, Kaushik, 2009: 370-371), as well as Albulescu (Albulescu, 2010: 81-98) working paper's author will use same weights for all selected economic indicators in order to establish Latvian financial stability index.

Similar to Albulescu approach this working paper's author will use empirical normalization which in its nature is similar to mathematical normalization where lower and upper limits define interval from 0 to 100 which is achieved using formula (1) and multiplying its right part with 100.

Empirical normalization method is based on formula:

$$
Y_{t}=X_{t}-\min X \max X-\min X,
$$

where $Y_{t}$ is variable's normalized time series value for period $t$;

$X_{t}$ is variable's actual time series value for period;

$\min X$ and $\max X$ - respectively variable's time series minimum and maximum values.

Normalization of selected indicators and establishment of Latvian financial system stability index's subindices have been performed using formula (1). That results in definition of Latvian financial system stability index. Depending on sub-factors' impact vectors reverse formula has also been applied to avoid cases when normalized factors eliminate each other's impact on sub-index dynamics (for example, inflation level increase negatively impacts financial vulnerability index while current account deficit improvement positively impacts financial vulnerability index).

$$
Y_{t}=\frac{\max (X)-X_{t}}{[\max (X)-\min (X)]}
$$

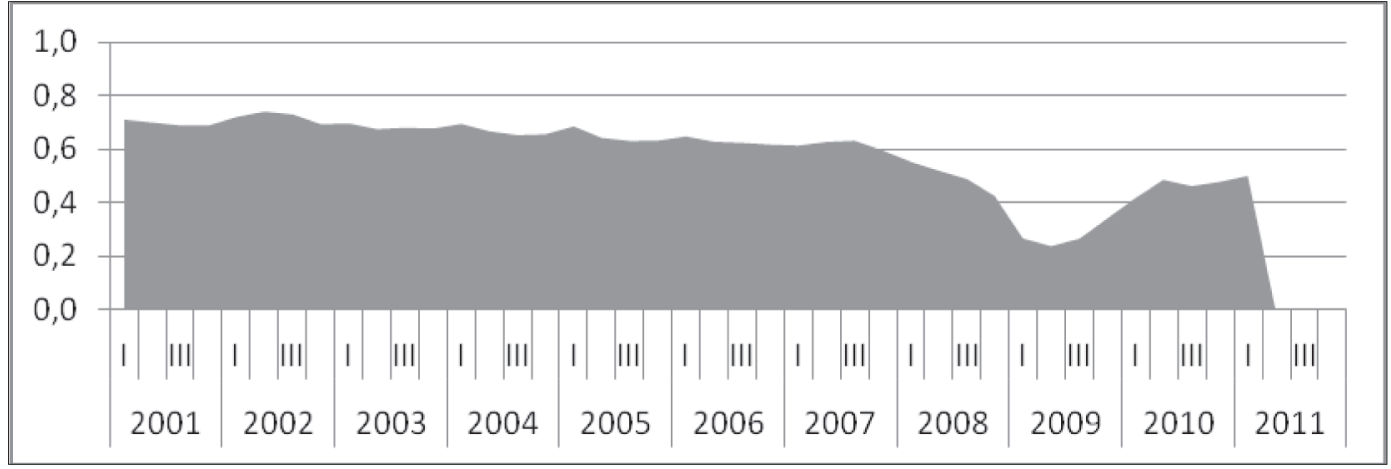

Figure 3. Latvian financial system stability index

Source: data from FCMC, Bank of Latvia, CSB, author's calculations

One could point out that Latvian financial system stability has been consistently decreasing starting from 2001 (see Figure 3). Especially rapid drop in Latvian financial system stability has been observed starting from early 2008, marking economic problems related to Latvian economy overheating.

Firstly, analysing Latvian financial system stability index comprising sub-indices one can conclude that each and every sub-index has different development trend dynamics that are supported by very low level 
of mutual correlation (see Table 2). That means that dynamics of every developed sub-index show unique economic processes defining Latvian financial system's stability.

Secondly, sub-indices analysis allows to determine that Latvian financial vulnerability began to worsen in 2005, however, Latvian financial stability downward movement started in 2002, that in its turn shows the necessity for Latvian economic policy makers to get more actively involved in preventing growing risks of economy.

It is worth to add that overall Latvian financial system has been relatively stable up until 2008, but this was due to the fact that one part of this system has been experiencing positive changes while the other has been accumulating growing risks. Therefore, analysing only overall Latvian financial system stability index and ignoring sub-indices can lead to missing important signals on Latvian financial system stability potential risks and as a result being late on applying adequate improvement measures.

Table 2. Correlation among sub-indices of Latvian financial system stability index quarterly movements

\begin{tabular}{|l|l|l|l|l|l|}
\hline & $\begin{array}{l}\text { Latvian } \\
\text { financial } \\
\text { development } \\
\text { index }\end{array}$ & $\begin{array}{l}\text { Latvian } \\
\text { financial } \\
\text { vulnerability } \\
\text { index }\end{array}$ & $\begin{array}{l}\text { Latvian } \\
\text { financial } \\
\text { stability index }\end{array}$ & $\begin{array}{l}\text { European } \\
\text { economic } \\
\text { environment } \\
\text { index }\end{array}$ & $\begin{array}{l}\text { European } \\
\text { financial } \\
\text { environment } \\
\text { index }\end{array}$ \\
\hline $\begin{array}{l}\text { Latvian financial } \\
\text { development index }\end{array}$ & 1.00 & & & & \\
\hline $\begin{array}{l}\text { Latvian financial } \\
\text { vulnerability index }\end{array}$ & -0.25 & 1.00 & & & \\
\hline $\begin{array}{l}\text { Latvian financial stability } \\
\text { index }\end{array}$ & 0.09 & 0.17 & 1.00 & & 1.00 \\
\hline $\begin{array}{l}\text { European economic } \\
\text { environment index }\end{array}$ & -0.05 & 0.00 & 0.10 & & 1.00 \\
\hline $\begin{array}{l}\text { European financial } \\
\text { environment index }\end{array}$ & 0.20 & 0.24 & -0.05 & & 0.08 \\
\hline
\end{tabular}

Source: author's calculations

As it has already been mentioned, Latvian financial stability index comprises 5 sub-indices and gets calculated as a weighted average with identical weights assigned to all sub-indices, in this way assuming same level of influence for all involved indices. First of them is Latvian financial development index (see Figure 4). As it can be seen from the Figure since joining the EU Latvian financial development index has been gradually improving up until the beginning of 2008.

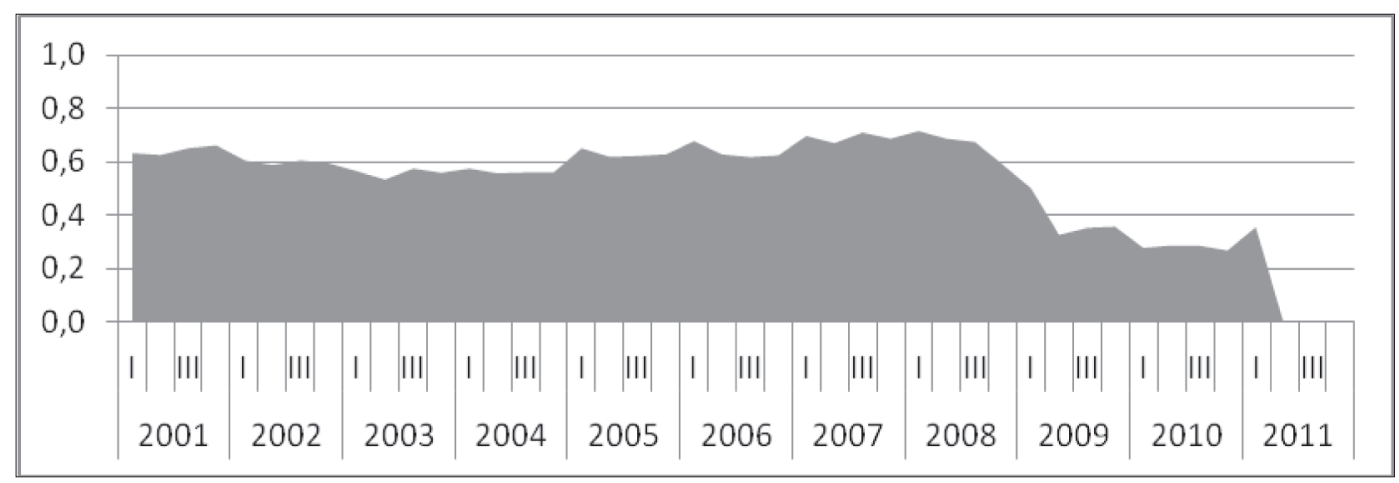

Figure 4. Latvian financial development index

Source: data from FCMC, Bank of Latvia, CSB, author's calculations 
Latvian financial vulnerability index is the next component of Latvian financial system's stability index (see Figure 5). Here we can see a completely different Figure. It is clearly seen that Latvian financial vulnerability index began to decrease starting from the second half of 2005, thus pointing at increasing economic risks. This period corresponds to the beginning of Latvian economy overheating.

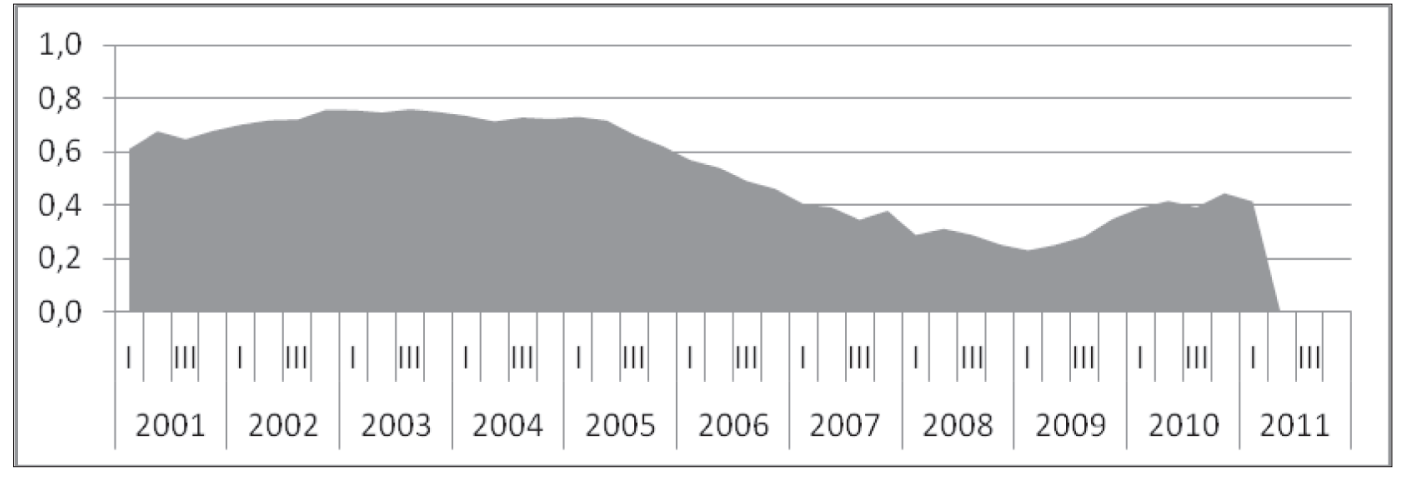

Figure 5. Latvian financial vulnerability index

Source: data from FCMC, Bank of Latvia, CSB, author's calculations

Poor quality assets write-offs and cessions to related $3^{\text {rd }}$ party companies artificially improve banks' financials. Therefore there is a risk that it is impossible to reflect those actions using econometric modelling based on fundamental economic factors.

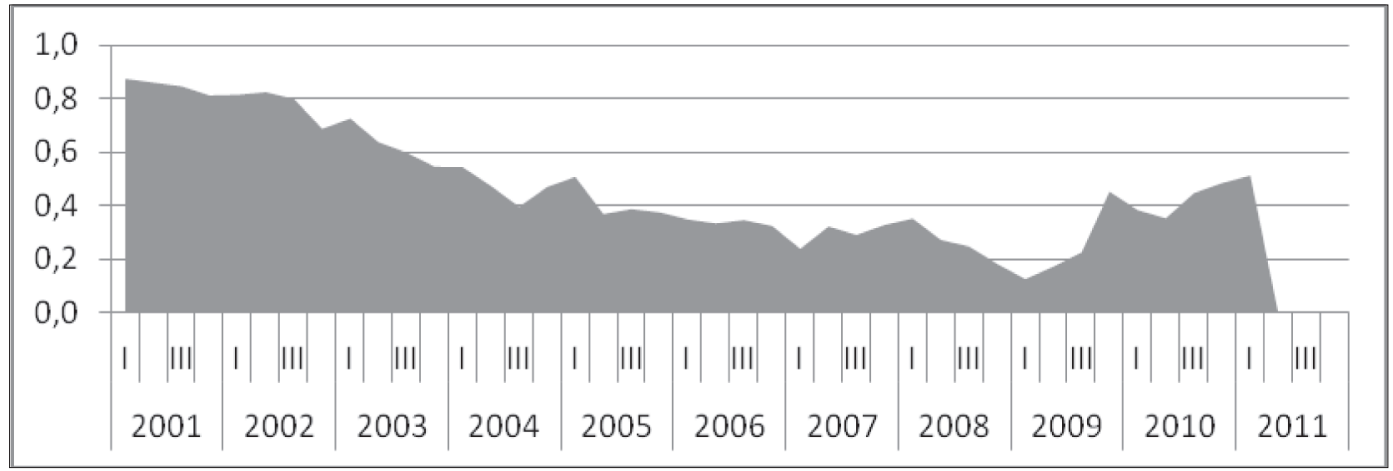

Figure 6. Latvian financial stability index

Source: data from FCMC, Bank of Latvia, CSB, author's calculations

Second to the last index that is included in Latvian financial system stability index is European economic environment index (see Figure 7). European economic environment index dynamics reflect European economy's cyclical development. It is interesting to note that European economic environment index started to notably worsen from as early as the beginning of 2008; it mainly happened due to unfavourable price dynamics in world markets.

Analysing last sub-index of Latvian financial system stability index it can be derived that in time period from 2002 to 2008 European financial environment was very favourable and sustainable (see Figure 8). However, world financial crisis has rapidly changed the Figure, shifting European financial environment index down to very unfavourable. It has remained at that level throughout 2009. In 2010 conditions have improved, but European financial environment has not reached even half of what it has been before, pointing at structural issues in some of European countries. 


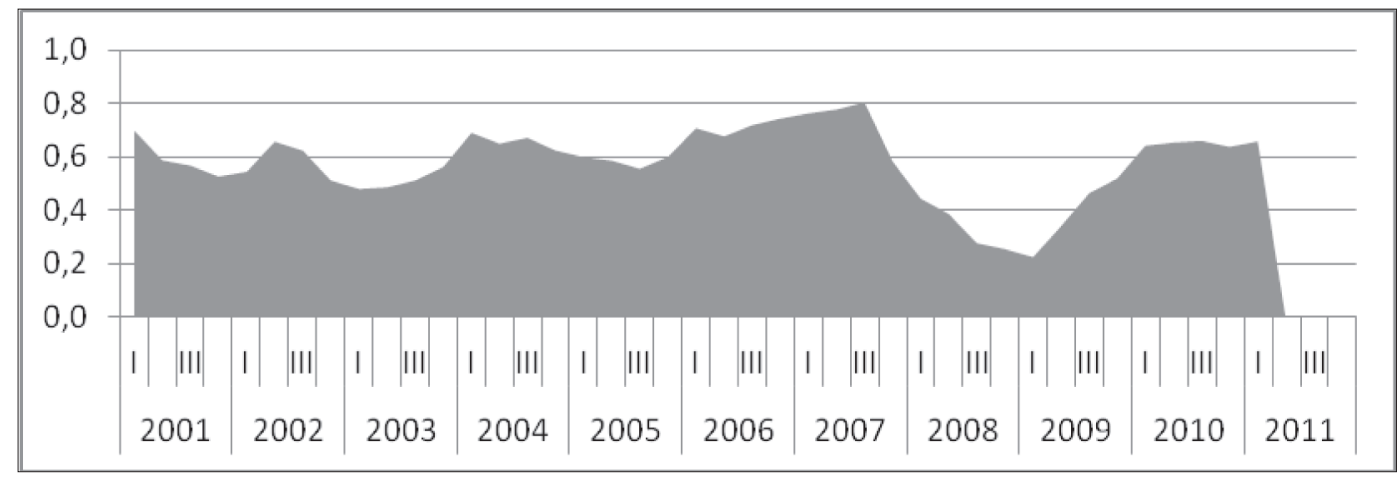

Figure 7. European economic environment index

Source: data from Eurostat, CESifo, author's calculations

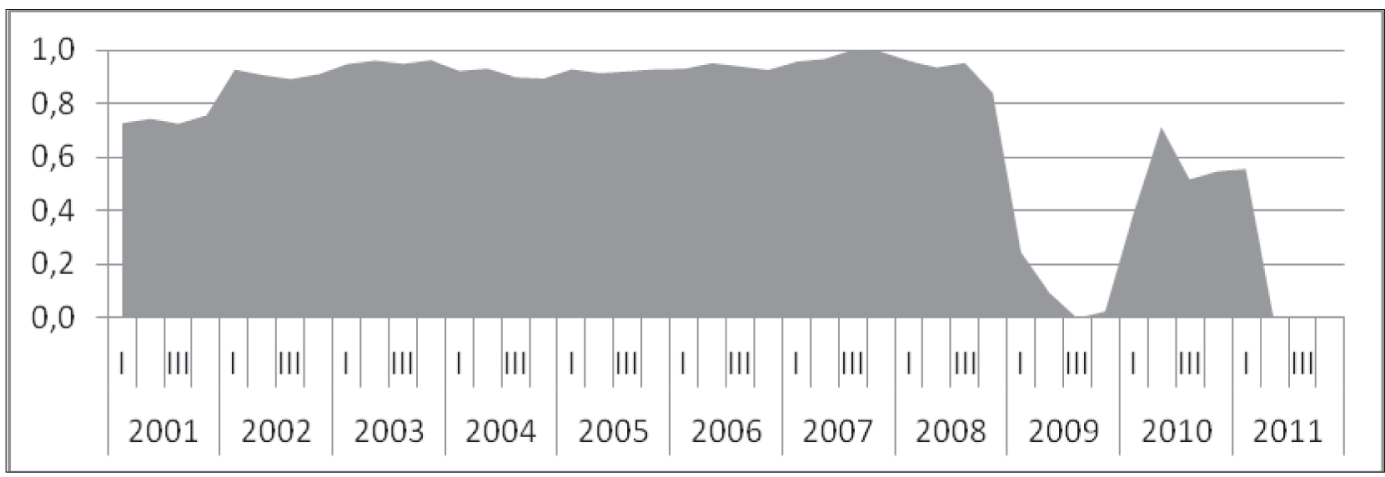

Figure 8. European financial environment index

Source: data from Eurostat, CESifo, author's calculations

Evaluating all developed indices together it can be concluded that they reflect situation in Latvia and world in a very efficient manner. Speaking of rapid decline in Latvian financial stability index in 2008 it is evident that it pointed at the necessity of quick response measures from economy policy makers in order to prevent situation's further worsening. It either has not been done or has not been done effectively. But even more interesting conclusions can be drawn from established sub-indices dynamics analysis.

\section{Latvian financial system stability index modelling}

Econometric error correction model has been developed in order to assess macroeconomic fundamental factors' impact on Latvian financial stability index dynamics. This model belongs to the class of dynamic regression models and is used to analyse short-term impacts. It comprises two parts:

- long-term equation;

- short-term equation with error correction factor.

Long-term equation reflects fundamental variable impact on dependent variable and is based on longterm regularities that exist among economic time series used in modelling. In other words, mutually cointegreted economic time series have to be used while assessing long-term econometric equation. Cointegration power must be 1 , or in other words cointegration analysis must conclude that there is only one cointegration vector among used time series. This would mean that there is long-term correlation between time series and that it can be written down in one equation. 
Theoretical form of long-term equation for the econometric model in question can be written down as follows:

$$
F S I_{t}=c+\sum_{i=1}^{n} \beta_{i} F_{i, t}+\varepsilon_{t},
$$

where $c$ - constant, $F S I_{t}$ - Latvian financial stability index at time period $t$;

$c$ is constant of the equation, $F_{i, t}$ is macroeconomic fundamental factor $i$ at time period $t$ and $\varepsilon_{t}$ is regression error at time period $t$.

Econometric hypothesis on $\beta$ coefficient signs in equation 3 will be defined after establishment of assessable econometric model with specific macroeconomic factors.

Construction of short-term equation with error correction factor is the second step of error correction model creation:

$$
\Delta F S I_{t}=c+\sum_{i=1}^{n} \alpha_{t} \Delta F_{i, t}+\gamma \varepsilon_{t-1}+\varepsilon_{t}
$$

where $\Delta$ represents difference, $\gamma$ is error correction coefficient, $\varepsilon_{t}$ is regression error in time period $t$.

Actual econometric model of long-term equation can be depicted in following way:

$$
F S I_{t}=c+\beta_{1} F_{1, t}+\beta_{2} F_{2, t}+\beta_{3} F_{3, t}+\beta_{4} F_{4, t}+\beta_{5} F_{5, t}+\beta_{6} F_{6, t}+\varepsilon_{t}
$$

Where:

$F_{1}$ - Ratio of foreign currency loans to nominal GDP in period $t$;

$F_{2}-3$ month interbank market interest rate RIGIBOR in period $t$;

$F_{3}$ - Nominal effective currency exchange rate (logarithm);

$F_{4}$ - Real workforce effectiveness (logarithm);

$F_{5}-$ Actual real GDP level deviation from potential real GDP to real GDP in period $t$;

$F_{6}$-Actual unemployment level deviation from structural unemployment level in period $t$.

In order to evaluate level of structural unemployment and potential level of real GDP Hodrick-Prescott filter has been used. It allows separating short and long-term fluctuations from the economic variable, thus evaluating long-term development trend of the variable; this trend is traditionally treated as structural trend or potential level. During variable filtering standard Hodrick-Prescott's filter "smoothing" coefficient has been used - the one that is normally used for smoothing quarterly data $\lambda=1600$.

Results of econometric modelling of Latvian financial stability index for long-term equation are reflected in next table (see Table 3). During econometric modelling 6 out of 14 selected fundamental indicators that characterize economic development showed the best results. As it can be seen all evaluated coefficients are of statistical importance and their signs comply with previously expressed economic hypothesis. Variables variances within the econometric model explain more than $96 \%$ of long-term fluctuations of Latvian financial stability index. 
Table 3. Modelling Latvian financial stability: long-term equation result

\begin{tabular}{|c|c|c|c|c|}
\hline \multicolumn{5}{|l|}{ Dependent variable: $\Delta F S I_{t}$} \\
\hline \multicolumn{5}{|c|}{$\begin{array}{l}\text { Method: Least squares } \\
\text { Sample: } 2001 \text { year } 2 \text { quarter - } 2011 \text { year } 1 \text { quarter } \\
\text { Included observations: } 41\end{array}$} \\
\hline Variable & Coefficient & Std. Error & t-Statistic & Prob. \\
\hline Constant & -3.193 & 1.789 & -1.785 & 0.083 \\
\hline $\begin{array}{l}\text { ratio of foreign currency loans } \\
\text { to nominal GDP }\end{array}$ & -0.128 & 0.014 & -9.246 & 0.000 \\
\hline $\begin{array}{l}3 \text { month interbank market } \\
\text { interest rate RIGIBOR }\end{array}$ & -0.011 & 0.001 & -8.115 & 0.000 \\
\hline $\begin{array}{l}\text { Nominal effective currency } \\
\text { exchange rate }(\log )\end{array}$ & 0.749 & 0.340 & 2.205 & 0.034 \\
\hline $\begin{array}{l}\text { Real workforce effectiveness } \\
\text { (logarithm) }\end{array}$ & 0.783 & 0.260 & 3.006 & 0.005 \\
\hline $\begin{array}{l}\text { Actual real GDP level } \\
\text { deviation from potential real } \\
\text { GDP to real GDP }\end{array}$ & 0.770 & 0.227 & 3.386 & 0.002 \\
\hline $\begin{array}{l}\text { Actual unemployment level } \\
\text { deviation from structural } \\
\text { unemployment level }\end{array}$ & 0.012 & 0.005 & 2.557 & 0.015 \\
\hline \multicolumn{2}{|l|}{ R-squared } & \multicolumn{2}{|c|}{ Mean dependent var } & 0.587 \\
\hline \multicolumn{2}{|l|}{ Adjusted R-squared } & \multicolumn{2}{|c|}{ S.D.dependent var } & 0.133 \\
\hline \multicolumn{2}{|l|}{ S.E. of regression } & \multicolumn{2}{|c|}{ Akaike info criterion } & -4.362 \\
\hline \multicolumn{2}{|l|}{ Sum of squared resid } & \multicolumn{2}{|c|}{ Schwarz criterion } & -4.069 \\
\hline \multicolumn{2}{|l|}{ Loglikelihood } & \multicolumn{2}{|c|}{ Hannan-Quinn criter. } & -4.255 \\
\hline \multicolumn{2}{|l|}{ F-statistic } & \multicolumn{2}{|c|}{ Durbin-Watson stat } & 1.679 \\
\hline Prob(F-statistic) & 0.00 & & & \\
\hline
\end{tabular}

Source: author's calculation

Results gained from evaluating the long-term econometric model are interpreted as follows:

- Foreign currency loan weight increase in GDP by 10 bps reduces Latvian financial stability by 1.28 bps with other variables remaining unchanged.

- 3-month RIGIBOR increase by 1 bps reduces Latvian financial stability index by 0.01 bps with other variables remaining unchanged.

- Nominal effective exchange rate increase by $10 \%$ improves Latvian financial stability index by 7.49 bps with other variables remaining unchanged.

- Real workforce effectiveness increase by $10 \%$ improves Latvian financial stability index by 7.83 bps with other variables remaining unchanged.

- Actual real GDP positive (negative) deviation from potential real GDP to real GDP ratio increase by 1 bps improves (worsens) Latvian financial stability index by 0.77 bps with other variables remaining unchanged.

- 1 bps increase of actual unemployment level's positive (negative) deviations from structural unemployment level improves (worsens) Latvian financial stability index by $0.01 \mathrm{bps}$ with other variables remaining unchanged.

It is worth noting that quality of evaluated econometric model is good. Its F-statistics results prove its correct structure and Durbin-Watson statistics is satisfactory, pointing at autocorrelation absence amongst model errors. 
Following econometrical tests has been performed to make sure that there is cointegration between model variables, the variables are stable, there is no error series correlation and etc.: Unit root, Dickey-Fuller, Breusch-Godfrey regression error, Heteroscedasticity and CUSUM.

Due to paper size restrictions author is not able to provide full description and necessity of performed tests.

Evaluating long-term econometric model it is possible to evaluate short-term error correction model, too, based on its theoretical definition (2):

$$
F S I_{t}=c+\beta_{1} F_{1, t}+\beta_{2} F_{2, t}+\beta_{3} F_{3, t}+\beta_{4} F_{4, t}+\beta_{5} F_{5, t}+\beta_{6} F_{6, t}+\gamma \varepsilon_{t-1}+D_{2009: 4}+\varepsilon_{t}
$$

In addition to selected fundamental variables dummy variable $D_{2009: 4}$ has been added - its value is 0 at all periods except for Q4 of 2009 when its value is 1 .

It has been done because of the fact that in given periods selected fundamental variables couldn't accurately define short-term dynamics of Latvian financial stability index. This could be due to the banking sector actions that resulted in non-earning portfolio write-off and bad quality assets hand over to 3rd parties with the purpose to show better financial results on books. In order to eliminate effect of those manipulations on econometric model's evaluation, dummy variables have been introduced.

Due to paper size restrictions author is not able to provide full description of short-term equation calculation.

\section{Conclusions and suggestions}

Following conclusions and suggestions are based on author's performed research and analysis:

1. Newly established index and its accompanying methodology can be further used in follow-up research and Latvian financial stability index improvement.

2. Latvian economic policy makers need Latvian financial system stability index that can be: easily calculated; easily interpreted; easily communicated across; defined econometrically using fundamental economic factors; used for taking timely response measures on financial system stability emerging threats.

3. From 14 selected fundamental economic factors only 6 proved their econometric modelling usefulness. These factors are: ratio of foreign currency loans to nominal GDP; 3 month interbank market interest rate RIGIBOR; nominal effective currency exchange rate; real workforce effectiveness; actual real GDP level deviation from potential real GDP to real GDP; actual unemployment level deviation from structural unemployment level.

4. Latvian financial system stability index established in this working paper would have allowed to determine economy's critically grown risks in 2008 and would have given at least half a year before the beginning of economic correction to perform loss minimising measures.

\section{References}

Albulescu, C. T. (2010). Forecasting the Romanian financial system stability using a stochastic simulation model. Romanian Journal of Economic Forecasting, p. 81-98.

Bank of Latvia. Website: http://www.bank.lv/en/statistics/activities/

Blaise, G., Kaushik, J. (2009). Measures of financial stability - a review. IFC Bulletin, p. 365-380.

CSB, Central Statistical Bureau of Latvia. Website: http://www.csb.gov.lv/en

CESifo, Research "Ifo" Institute of the Center for Economic Studies (CES). Website: http://www.cesifo-group.de/portal/page/portal/ifoHome

Čihák, M. (2007). Systemic loss: a measure of financial stability. Czech Journal of Economics and Finance, Vol. 1-2 (57), p. 5-26.

EUROSTAT, statistical office of the European Union. Website: http://epp.eurostat.ec.europa.eu/portal/page/portal/eurostat/home

FCMC, Financial and Capital Market Commission. Website: http://www.fktk.lv/en/statistics/latest/ 
Gray, D., Merton, R., Bodie, Z. (2007). New framework for measuring and managing macrofinancial risk and financial stability. NBER Working Paper.

Hannoun, H. (2010, February). Towards a global financial stability framework. Retrieved August 25, 2011, from Bank International Settlements: http://www.bis.org/speeches/sp100303.pdf

Hawkins, J., Klau, M. (2000). Measuring potential vulnerabilities in emerging market economies. Bank for International Settlements.

IMF. (2006, April 4). Financial Soundness Indicators: Compilation Guide. Retrieved August 25, 2011, from International Monetary Fund: http://www.imf.org/external/pubs/ft/fsi/guide/2006/index.htm

Nelson, W., Perli, R. (2005). Selected indicators of financial stability. 4th Joint Central Bank Research Conference on "Risk Measurement and Systemic Risk". ECB Frankfurt am Main.

Turner, A. (2010, March 17). What do banks do, what should they do, and what public policies are needed to ensure best results for the real economy? Retrieved august 25, 2011, from Financial Services Authority: http://www.fsa. gov.uk/pubs/speeches/at_17mar10.pdf

\title{
FINANSINIO STABILUMO INDEKSO MODELIAVIMAS LATVIJOS FINANSINËJE SISTEMOJE
}

\author{
KiriLs KondRatovs \\ Latvijos universitetas (Latvija)
}

\section{Santrauka}

Finansiniai neramumai gali brangiai kainuoti. Ypač tai pasakytina apie sisteminius įvykius finansų rinkose, tokius kaip bankų krizès, kurie skaudžiai paveikia visą visuomenę. Todèl svarbu numatyti tokių ivykiu riziką, kad būtu galima išvengti nelaimès ir užtikrinti finansini stabilumą. Šio straipsnio autorius analizuoja Latvijos finansų sistemos trapumą ir priklausymą nuo svyravimų pasaulineje ekonomikoje bei pasikeitimu tarptautinio kapitalo srautuose, kuriuos galima îvertinti kompleksiniu finansinès sistemos stabilumo indeksu. Kiekvienas iš nustatytų subindeksų atskleidžia unikalius ekonomikos procesus, kurie lemia Latvijos finansinès sistemos stabilumą. Subindeksų analizè taip pat leidžia nustatyti, kad Latvijos finansinis pažeidžiamumas èmė sparčiai didèti nuo 2005 metų (blogèti pradejjo dar 2002 metais), taigi Latvijos ekonominès politikos kūrèjai turètų aktyviau ịsitraukti ị kylančios rizikos ekonominei sistemai mažinimą. Latvijos finansinès sistemos stabilumo indeksas ir metodologija, pateikti šitame straipsnyje, gali būti panaudoti tolesniuose tyrimuose ir Latvijos finansinio stabilumo indeksui tobulinti.

PAGRINDINIAI ŽODŽIAI: finansinè sistema, finansinis stabilumas, indekso modeliavimas.

JEL KODAI: G01 